\title{
Conventional and microwave-assisted extraction for bioactive compounds from dried coffee cherry peel by-products and antioxidant activity of the aqueous extracts
}

\author{
Somruedee Thaiphanit*, Warintorn Wedprasert, Aristha Srabua \\ Department of Food Technology, Faculty of Science, Siam University, Bangkok 10160 Thailand \\ *Corresponding author, e-mail: somruedee.tha@siam.edu
}

Received 16 Oct 2019

Accepted 2 Feb 2020

\begin{abstract}
The purposes of this research are to measure the chemical composition, bioactive compounds and antioxidant activities in dried coffee cherry peel by products from the mature fruits of Arabica and Robusta coffee beans and to determine the effects of conventional and microwave-assisted extraction techniques on the quantities of those compounds and antioxidant activities in aqueous extracts. Bioactive compounds from the by-products were extracted with water using either conventional or microwave-assisted extraction equipment at temperatures of 80,90 and $100{ }^{\circ} \mathrm{C}$ or at microwave power settings of 450, 630 and $900 \mathrm{~W}$, respectively, for various time period (1-5 min). The results showed that Arabica coffee cherry peel extracts exhibited significantly higher levels of bioactive compounds (except total carotenoids) and antioxidant activities than the Robusta coffee cherry peel extracts. The highest quantities of bioactive compounds in the aqueous extracts were found with conventional extraction. However, microwave-assisted extraction was far more efficient for compounds with antioxidant activity. The optimum extraction process for caffeine and carotenoids was a conventional extraction at $100{ }^{\circ} \mathrm{C}$ with a 5 min holding time using either Robusta or Arabica coffee cherry peels.
\end{abstract}

KEYWORDS: coffee cherry peel, caffeine, bioactive compounds, conventional extraction, microwave-assisted extraction

\section{INTRODUCTION}

Coffee is an important product consumed daily by millions of people worldwide. In Thailand, two types of coffee are produced: Arabica (Coffea arabica L.) in the north, and Robusta (Coffea canephora Pierre ex A. Froehner) in the south. They are a significant source of income in Thailand as the country is the third largest Asian coffee producer (after Vietnam and Indonesia). Thai coffee farmers produced 11007 and 23887 tons of Arabica and Robusta, respectively, in 2018/2019 [1,2]. In Thailand, coffee bean production has experienced continuous growth over the past few years. As a consequence, large amounts of dried coffee cherry peel by-products resulted from coffee bean (green bean) production by both dry and wet processes. The dry process is the oldest method and it is generally used for Robusta coffee. After harvest, the entire cherries are first cleaned and placed on tables or in thin layers on the ground to dry in the sun. The dried cherries are stored in bulk inside silos until they are sent to the mill where hulling, sorting, grading and bagging take place. All the outer layers of the dried cherries are removed in one milling step. Alternatively, the skin of the cherries and some of the pulp are removed by mechanically pressing the fruit in water through a screen in a wet process. This is generally done with Arabica coffee. The bean will still have a significant amount of pulp clinging to it that needs to be removed before drying $[3,4]$. Of the total weight of the coffee, $30-50 \%$ is the skin, pulp, mucilage and parchment, plus the by-products of green bean production depending on the type of process done. These are valuable materials that can be used for various purposes, including extraction of bioactive compounds such as caffeine, carotenoids and polyphenols [3]. Additionally, beverages can be derived from either coffee cherry husks or coffee cherry pulp [5]. However, the composition of the byproducts varies depending on the coffee species and processing methods used. The main by-products of dry processing are the skin, pulp, mucilage and 
parchment in a single mixed fraction. Wet processing yields a single by-product that consists of the skin and pulp [3].

Caffeine and bioactive compounds from plants have received considerable attention due to their potential health benefits such as their potential protection against chronic degenerative diseases, cancers and cardiovascular diseases as well as other illnesses that can be mitigated by antioxidant activity $[6,7]$. Additionally, cyanadin-3-rutinoside, which is found in coffee pulp, is an important anthocyanin with antioxidant, anticarcinogenic, anti-inflammatory and antihypoglycemic effects [7]. Moreover, lutein and $\beta$-carotene which are carotenoids in coffee cherry peels $[8,9]$ may be a potential source of these valuable materials. Although bioactive compounds from plant materials can be extracted using various classical extraction techniques, qualitative and quantitative removal of bioactive compounds from plant materials relies on selection of the best extraction method [10]. Conventional extraction techniques using water as a solvent can be modified by changing the extraction temperature. This approach has been applied to the extraction of bioactive compounds from plants [11]. However, the disadvantages of conventional extraction are its longer extraction time and poor extraction selectivity. Moreover, many bioactive compounds are thermally labile, so they are degraded at high temperatures [10]. Microwave-assisted extraction is considered a novel method for extracting soluble products into a fluid from a wide range of materials [12]. The extraction mechanism of microwave-assisted extraction involves three sequential steps. First, solutes are separated from active sites of a sample matrix under increased temperature and pressure. Second, a solvent diffuses into the sample matrix. Finally, the solutes are released from the sample matrix into the solvent [13]. There are several benefits of microwave-assisted extraction, including a more rapid heating for extraction of bioactive substances, lower thermal gradients, reduced equipment size and increased extract yield. Moreover, it can extract bioactive compounds more rapidly with better recovery than that with conventional extraction processes [10]. Therefore, microwaveassisted extraction is an attractive alternative to conventional extraction. It is preferred in the case of bioactive compound extraction. However, there is no information regarding the effects of microwaveassisted extraction on the quantities of bioactive compound and antioxidant activities in aqueous extracts of coffee cherry peel by-products. Therefore, the objective of the present work was to analyze the chemical composition, bioactive compounds and the antioxidant activities in extracts of coffee cherry peel by-products from mature fruits of $C$. arabica $\mathrm{L}$. and C. canephora Pierre ex A. Froehner. Furthermore, it aimed to study the effects of conventional and microwave-assisted extraction on the quantities of bioactive compounds and antioxidant activities of aqueous extracts of these materials.

\section{MATERIALS AND METHODS}

\section{Raw materials and chemical reagents}

Coffee cherry peel by-products of the mature fruits of $C$. arabica L. (Arabica) produced by wet processing and C. canephora Pierre ex A. Froehner (Robusta) by dry processing from green bean production were obtained from Akha Ama Coffee (Chiang Mai, Thailand) and ST Coffee and Sangtong 1982 Co., Ltd (Chumphon, Thailand), respectively. All chemicals used in the experiments were purchased as analytical grade reagents from Scientific Equipment Co. Ltd., Roongsarp-Chemical (Partnerships), S.M. Chemical Supplies Co., Ltd. and CTI \& Science Co. Ltd., Bangkok, Thailand.

\section{Preparation of dried coffee cherry peels}

Contaminants such as stones, twigs and coffee beans were removed from the coffee cherry peels. The coffee cherry peels were dried at $45^{\circ} \mathrm{C}$ to a moisture content of less than $10 \%$. Then, they were ground using a blender (Philips HR 2061, Indonesia) at room temperature until obtaining a homogeneous powder that could pass a No. 10 mesh screen and kept in sealed aluminum foil bags at room temperature until they were used.

\section{Preparation of extracts}

Twenty-five grams of dried coffee cherry peel powder were used for each treatment. After extraction for the selected time, the suspension temperature was measured followed by centrifugation at 1000 rpm for $10 \mathrm{~min}$. The supernatant was collected and its volume was brought to $500 \mathrm{~mL}$ with distilled water before the determinations of caffeine, carotenoid, phenolic and antioxidant activity levels.

\section{Conventional extraction}

Distilled water was added to the dried coffee cherry peel powder at a ratio of $1: 20(\mathrm{w} / \mathrm{v})$ with a 15 min holding time at room temperature followed by heating in a water bath at temperatures of 80,90 or $100{ }^{\circ} \mathrm{C}$ for various holding times, i.e., 1,3 and 5 $\min$. 


\section{Microwave-assisted extraction}

Distilled water was added to dried coffee cherry peel powder at a ratio of 1:20 (w/v) with a 15 min holding time at room temperature followed by heating in a microwave oven at 450,630 and 900 $\mathrm{W}$ power levels for various holding times, i.e., 1, 3 and 5 min.

\section{Chemical composition analysis}

The chemical composition of dried coffee cherry peel was determined according to AOAC standard methods 962, 09-992.06 [14]. The carbohydrate content was determined as a difference between the total mass of material and the sum of the other components.

\section{Caffeine}

For coffee cherry peel powder, one gram of dried powder was extracted with $250 \mathrm{~mL}$ of hot water (HPLC grade) at $90^{\circ} \mathrm{C}$ with $5.0 \mathrm{~g}$ of $\mathrm{MgO}$ for $20 \mathrm{~min}$. The solution was filtered through Whatman No. 1 filter paper to remove solid materials after which HPLC-grade water was added to return the solution volume to $250 \mathrm{~mL}$. Then, the sample solution was passed through a $0.45 \mu \mathrm{m}$ membrane filter into a $1 \mathrm{~mL}$ glass vial. The vials were closed and kept at $-18^{\circ} \mathrm{C}$ until analyzed. The caffeine content was determined using an HPLC-DAD method. Standard solutions and samples were injected into the HPLC system (Agilent 1200, USA) using reversed-phase, Eclipse XDB-C18 columns (Agilent, USA). A diode array detector (Agilent, Germany) was set at 254 $\mathrm{nm}$ while the flow rate was $1 \mathrm{~mL} / \mathrm{min}$ at room temperature with a sample volume of $20 \mu \mathrm{L}$. The mobile phase was methanol and 1\% acetic acid in a 30:70 ratio [15]. The isocratic mode was used for mobile phase elution. A linearity test was performed using soluble caffeine standards in ethanol concentrations of $5,10,20$ and $50 \mu \mathrm{g} / \mathrm{mL}$. A standard curve between the concentration of caffeine standards and peak area was plotted. Caffeine content was determined using a linear regression of the standard calibration curve. For coffee extracts, $1 \mathrm{~mL}$ of the extract solution, which was filtered through 0.45 $\mu \mathrm{m}$ filters, was analysed for caffeine content by the HPLC-DAD method as above.

\section{Carotenoids}

Five grams of dried coffee cherry peel powder were weighed into an amber glass bottle that contained $25 \mathrm{~mL}$ acetone/ethanol (1:1) with $200 \mathrm{mg} / \mathrm{L}$ of butylated hydroxytoluene. An Ultra Turrax homogenizer was used for $5 \mathrm{~min}$ to mix the samples. Then, the extract was filtered through Whatman No. 1 filter paper to remove solid materials. This process was repeated until the solid materials became colorless according to a method of Kenny and O' Beirne [16]. The filtrates were each evaporated under a nitrogen gas flow to $25 \mathrm{~mL}$ and the absorbance at $470 \mathrm{~nm}$ was measured. For coffee extracts, $50 \mathrm{~mL}$ of the extracts were evaporated under vacuum in a rotary evaporator for $30 \mathrm{~min}$. Then, the viscous liquid was mixed with $25 \mathrm{~mL}$ solution of acetone/ethanol (1:1) containing $200 \mathrm{mg} / \mathrm{L}$ of butylated hydroxytoluene before measuring the absorbance at $470 \mathrm{~nm}$. Total carotenoids were calculated according to Gross [17].

\section{Phenolics}

Thirty grams of dried coffee cherry peel powder were extracted using $200 \mathrm{~mL}$ of $95 \%$ ethanol at room temperature in an amber glass bottle, and then stirred at $500 \mathrm{rpm}$ for 4 hours. It was then filtered through Whatman No. 1 filter paper to remove solid materials, evaporated under a vacuum to a final volume of $10 \mathrm{~mL}$ and kept in $2 \mathrm{~mL}$ amber glass vials at $-18^{\circ} \mathrm{C}$ until analyzed according to Masuda et al [18]. Total phenolic content was analysed by a colorimetric assay using a $10 \%$ FolinCiocalteu reagent. A standard curve of the reference substance (gallic acid) was made using five concentrations $(50-300 \mu \mathrm{g} / \mathrm{mL})$. The total phenolic content was determined using a linear regression of a standard calibration curve. For coffee extracts, $10 \mathrm{~mL}$ of the coffee extracts were used to analyse the total phenolic content via the colorimetric assay without sample preparation.

\section{Determination of antioxidant activity}

Sample solutions of phenolics were prepared to determine the antioxidant activities of the dried coffee cherry peel solutions; while $2.5 \mathrm{~mL}$ of the coffee extracts could be used directly. Antioxidant activity was analyzed using an ABTS assay according to Thaipong et al [19]. Five concentrations, $500 \mu \mathrm{M}$ of Trolox, were used as standard solutions. Antioxidant activity was determined using a linear regression of the standard curve.

\section{Statistical analysis}

A completely randomized design (CRD) and independent $t$-tests were used to compare mean values for the purpose of assessing the effects of coffee 
Table 1 The chemical composition, bioactive compounds, and antioxidant activity of dried Arabica and Robusta coffee cherry peel by-products.

\begin{tabular}{|c|c|c|}
\hline Parameter & Arabica & Robusta \\
\hline Carbohydrate (\%) & $45.78 \pm 0.89^{b}$ & $47.73 \pm 0.97^{\mathrm{a}}$ \\
\hline Crude fiber $(\%)^{\text {ns }}$ & $27.97 \pm 1.28$ & $28.76 \pm 1.56$ \\
\hline Protein (\%) & $12.69 \pm 0.23^{\mathrm{a}}$ & $11.37 \pm 0.19^{\mathrm{b}}$ \\
\hline Moisture (\%) ${ }^{\mathrm{ns}}$ & $9.17 \pm 0.06$ & $9.16 \pm 0.08$ \\
\hline Ash (\%) & $0.11 \pm 0.02^{\mathrm{b}}$ & $0.23 \pm 0.06^{\mathrm{a}}$ \\
\hline Fat $(\%)$ & $4.28 \pm 0.00^{\mathrm{a}}$ & $2.73 \pm 1.16^{\mathrm{b}}$ \\
\hline Caffeine $(\mu \mathrm{g} / \mathrm{g})$ & $88.20 \pm 0.00^{\mathrm{a}}$ & $13.70 \pm 0.00^{\mathrm{b}}$ \\
\hline Total phenolics $(\mu \mathrm{g} / \mathrm{g})$ & $1210.2 \pm 30.0^{\mathrm{a}}$ & $1040.0 \pm 90.4^{b}$ \\
\hline Total carotenoids $(\mu \mathrm{g} / \mathrm{g})$ & $60.73 \pm 1.30^{\mathrm{b}}$ & $108.18 \pm 2.41^{\mathrm{a}}$ \\
\hline Antioxidant activity $(\mu \mathrm{M} / \mathrm{g})$ & $710.43 \pm 32.76^{\mathrm{a}}$ & $600.46 \pm 25.07^{\mathrm{b}}$ \\
\hline
\end{tabular}

species on the chemical constituents and antioxidant activities of the dried coffee cherry peel byproducts. A $2 \times 9$ factorial experiment in CRD was designed to study the effect of the extraction method on the chemical properties of the aqueous extracts. Differences between mean values were established using Duncan's new multiple range tests. These values were considered at a confidence level of $95 \%$. All experiments were performed in triplicate.

\section{RESULTS}

The levels of important chemical constituents and antioxidant activities of dried coffee cherry peel byproducts of mature Arabica and Robusta fruits from green bean production using wet and dry processing, respectively, are given in Table 1. Extracts of the various coffee species had significant differences in carbohydrate, protein, ash, fat, caffeine, total phenolics, and total carotenoid contents as well as antioxidant activity. Arabica coffee cherry peels exhibited significantly higher levels of bioactive compounds (except total carotenoids) and antioxidant activity than Robusta coffee cherry peels.

The chemical properties of the aqueous extracts from dried coffee cherry peel by-products using conventional extraction (CE) and microwave-assisted extraction (MAE) under various extraction conditions are given in Tables 2 and 3. The extraction parameters used resulted in significant differences in the chemical properties of the aqueous extracts. The highest quantities of bioactive compounds and antioxidant activities were found when using conventional extraction. The extraction trials with higher temperatures or power settings and longer times tended to recover caffeine and carotenoids more efficiently. Significantly lower quantities of total phenolics and antioxidant activity levels were observed in aqueous extracts subjected to temperatures higher than $90^{\circ} \mathrm{C}$. Conventional extraction yielded higher quantities of total carotenoids than microwave-assisted extraction. Increased temperature and holding time for conventional extraction or greater power and holding time for microwaveassisted extraction produced higher quantities of total carotenoids in the aqueous extracts. The current study demonstrates that conventional extraction could recover much higher quantities of bioactive compounds and compounds with antioxidant activity than microwave-assisted extraction.

\section{DISCUSSION}

Carbohydrate, crude fiber and protein were the most abundant components in the by-products, comprising 45.78-47.73\%, 28.76-27.97\%, and 11.37$12.69 \%$, respectively. Similar values were reported by Murthy \& Naidu [20] and Somashekar \& Anu Appaiah [21]. Both Arabica and Robusta by-products presented bioactive compounds and antioxidant activities. Similar results have been reported in coffee by-products by Esquivel \& Jiménez [3], Viñas et al [8] and Simkin et al [9]. Additionally, the by-products of mature fruits from Arabica green bean production consisted of caffeine and phenolics as well as other materials with antioxidant activity. The amounts of these by-products were significantly higher than those found in Robusta. This is probably due to the differences in coffee varieties and processing methods [3]. The coffee pulp contains natural antioxidants such as hydroxycinnamic acids, most of which are covalently bound to the cell wall. In the fermentation and washing of wet processed Arabica, these compounds can be released by spontaneous fermentation or enzymatic activity [22]. Robusta by-products yielded higher total carotenoids than Arabica counterparts due to differences inherent in the coffee species and green bean production method. Simkin et al [9] reported that the levels of phytoene synthase involved in the synthesis of carotenoids increased under stress conditions. These results show the potential of using the dried coffee cherry peel by-products as a natural source of bioactive compounds with antioxidant activity for possible associated potential health benefits.

The various types of extraction techniques used caused significant differences in quantities of bioactive compound and antioxidant activity in the aqueous extracts. The highest levels of caffeine, total phenolics, total carotenoids, and antioxidant ac- 
Table 2 The effects of conventional extraction (CE) and microwave-assisted extraction (MAE) on the quantities of bioactive compounds and antioxidant activity in the aqueous extracts from dried Arabica coffee cherry peel by-products.

\begin{tabular}{|c|c|c|c|c|c|c|c|}
\hline \multirow{2}{*}{$\begin{array}{l}\text { Method } \\
\text { CE }\end{array}$} & \multicolumn{2}{|c|}{ Extraction set-up } & \multirow{2}{*}{$\begin{array}{l}\text { Final } \\
\text { temp. }\end{array}$} & \multirow{2}{*}{$\begin{array}{l}\begin{array}{l}\text { Caffeine } \\
(\mu \mathrm{g} / \mathrm{mL})\end{array} \\
1.07 \pm 0.01^{\mathrm{fg}} \\
0.93 \pm 0.00^{\mathrm{j}} \\
1.04 \pm 0.01^{\mathrm{gh}}\end{array}$} & \multirow{2}{*}{$\begin{array}{c}\begin{array}{c}\text { Phenolic } \\
(\mu \mathrm{g} / \mathrm{mL})\end{array} \\
117.09 \pm 3.74^{\mathrm{h}} \\
83.06 \pm 3.84^{\mathrm{k}} \\
192.27 \pm 2.14^{\mathrm{a}}\end{array}$} & \multirow{2}{*}{$\begin{array}{l}\begin{array}{c}\text { Carotenoid } \\
(\mu \mathrm{g} / \mathrm{mL})\end{array} \\
12.71 \pm 0.34^{\mathrm{g}} \\
16.40 \pm 0.11^{\mathrm{f}} \\
16.91 \pm 0.83^{\text {ef }}\end{array}$} & \multirow{2}{*}{$\begin{array}{c}\begin{array}{c}\text { Antioxidant } \\
(\mu \mathrm{M} / \mathrm{mL})\end{array} \\
490.50 \pm 21.23^{\mathrm{c}} \\
588.31 \pm 23.37^{\mathrm{b}} \\
579.35 \pm 21.74^{\mathrm{b}}\end{array}$} \\
\hline & $80^{\circ} \mathrm{C}$ & $\begin{array}{l}1 \mathrm{~min} \\
3 \mathrm{~min} \\
5 \mathrm{~min}\end{array}$ & & & & & \\
\hline & $90^{\circ} \mathrm{C}$ & $\begin{array}{l}1 \mathrm{~min} \\
3 \mathrm{~min} \\
5 \mathrm{~min}\end{array}$ & $\begin{array}{l}90^{\circ} \mathrm{C} \\
90^{\circ} \mathrm{C} \\
90^{\circ} \mathrm{C}\end{array}$ & $\begin{array}{l}0.93 \pm 0.02^{\mathrm{j}} \\
1.33 \pm 0.02^{\mathrm{d}} \\
1.27 \pm 0.01^{\mathrm{e}}\end{array}$ & $\begin{array}{l}145.81 \pm 0.64^{\mathrm{c}} \\
141.54 \pm 3.59^{\mathrm{d}} \\
136.85 \pm 1.85^{\mathrm{e}}\end{array}$ & $\begin{array}{l}17.87 \pm 0.23^{\mathrm{e}} \\
22.23 \pm 1.58^{\mathrm{c}} \\
23.99 \pm 1.36^{\mathrm{b}}\end{array}$ & $\begin{array}{l}643.34 \pm 25.55^{\mathrm{a}} \\
435.82 \pm 16.17^{\mathrm{d}} \\
423.12 \pm 15.90^{\mathrm{d}}\end{array}$ \\
\hline & $100^{\circ} \mathrm{C}$ & $\begin{array}{l}1 \mathrm{~min} \\
3 \mathrm{~min} \\
5 \mathrm{~min}\end{array}$ & $\begin{array}{l}100^{\circ} \mathrm{C} \\
100^{\circ} \mathrm{C} \\
100^{\circ} \mathrm{C}\end{array}$ & $\begin{array}{l}1.37 \pm 0.01^{\mathrm{cd}} \\
1.02 \pm 0.02^{\mathrm{ghi}} \\
1.64 \pm 0.04^{\mathrm{a}}\end{array}$ & $\begin{array}{l}136.79 \pm 1.90^{\mathrm{e}} \\
139.04 \pm 1.58^{\mathrm{de}} \\
130.39 \pm 0.01^{\mathrm{f}}\end{array}$ & $\begin{array}{l}19.89 \pm 1.24^{\mathrm{d}} \\
25.52 \pm 1.45^{\mathrm{a}} \\
25.75 \pm 1.00^{\mathrm{a}}\end{array}$ & $\begin{array}{l}426.85 \pm 17.31^{\mathrm{d}} \\
591.37 \pm 23.03^{\mathrm{b}} \\
297.69 \pm 13.11^{\mathrm{e}}\end{array}$ \\
\hline \multirow[t]{3}{*}{ MAE } & $450 \mathrm{~W}$ & $\begin{array}{l}1 \mathrm{~min} \\
3 \mathrm{~min} \\
5 \mathrm{~min}\end{array}$ & $\begin{array}{l}36^{\circ} \mathrm{C} \\
51^{\circ} \mathrm{C} \\
59^{\circ} \mathrm{C}\end{array}$ & $\begin{array}{l}0.97 \pm 0.04^{\mathrm{ij}} \\
1.11 \pm 0.05^{\mathrm{f}} \\
1.23 \pm 0.06^{\mathrm{e}}\end{array}$ & $\begin{array}{c}155.91 \pm 3.31^{\mathrm{b}} \\
120.73 \pm 0.86^{\mathrm{h}} \\
98.47 \pm 2.31^{\mathrm{j}}\end{array}$ & $\begin{array}{l}1.89 \pm 0.03^{1} \\
3.03 \pm 0.25^{\mathrm{kl}} \\
3.47 \pm 0.16^{\mathrm{k}}\end{array}$ & $\begin{array}{l}396.92 \pm 23.60^{d} \\
406.47 \pm 34.01^{d} \\
405.71 \pm 25.34^{d}\end{array}$ \\
\hline & $630 \mathrm{~W}$ & $\begin{array}{l}1 \mathrm{~min} \\
3 \mathrm{~min} \\
5 \mathrm{~min}\end{array}$ & $\begin{array}{l}42^{\circ} \mathrm{C} \\
60^{\circ} \mathrm{C} \\
76^{\circ} \mathrm{C}\end{array}$ & $\begin{array}{l}1.01 \pm 0.05^{\mathrm{hi}} \\
1.26 \pm 0.01^{\mathrm{e}} \\
1.42 \pm 0.01^{\mathrm{c}}\end{array}$ & $\begin{array}{c}125.71 \pm 1.18^{\mathrm{g}} \\
119.57 \pm 1.08^{\mathrm{h}} \\
97.77 \pm 1.65^{\mathrm{j}}\end{array}$ & $\begin{array}{l}3.96 \pm 0.02^{\mathrm{jk}} \\
4.18 \pm 0.16^{\mathrm{jk}} \\
6.27 \pm 0.72^{\mathrm{i}}\end{array}$ & $\begin{array}{l}415.81 \pm 25.12^{d} \\
426.38 \pm 36.08^{d} \\
420.32 \pm 36.37^{d}\end{array}$ \\
\hline & $900 \mathrm{~W}$ & $\begin{array}{l}1 \mathrm{~min} \\
3 \mathrm{~min} \\
5 \mathrm{~min}\end{array}$ & $\begin{array}{l}43^{\circ} \mathrm{C} \\
71^{\circ} \mathrm{C} \\
89^{\circ} \mathrm{C}\end{array}$ & $\begin{array}{l}1.06 \pm 0.02^{\mathrm{fgh}} \\
1.37 \pm 0.02^{\mathrm{cd}} \\
1.55 \pm 0.03^{\mathrm{b}}\end{array}$ & $\begin{array}{r}120.71 \pm 1.29^{\mathrm{h}} \\
107.77 \pm 0.45^{\mathrm{i}} \\
82.25 \pm 0.11^{\mathrm{k}}\end{array}$ & $\begin{array}{l}2.85 \pm 0.04^{\mathrm{kl}} \\
5.08 \pm 0.11^{\mathrm{ij}} \\
8.72 \pm 0.21^{\mathrm{h}}\end{array}$ & $\begin{array}{l}420.65 \pm 32.47^{d} \\
426.95 \pm 34.54^{d} \\
433.51 \pm 33.15^{d}\end{array}$ \\
\hline
\end{tabular}

The same letters in the same column indicate that values are not significantly different $(p>0.05)$.

Table 3 The effects of conventional extraction (CE) and microwave-assisted extraction (MAE) on the quantities of bioactive compounds and antioxidant activity in the aqueous extracts from dried Robusta coffee cherry peel by-products.

\begin{tabular}{|c|c|c|c|c|c|c|c|}
\hline \multirow{2}{*}{$\begin{array}{l}\text { Method } \\
\text { CE }\end{array}$} & \multicolumn{2}{|c|}{ Extraction set-up } & \multirow{2}{*}{$\begin{array}{c}\begin{array}{c}\text { Final } \\
\text { temp. }\end{array} \\
80^{\circ} \mathrm{C} \\
80^{\circ} \mathrm{C} \\
80^{\circ} \mathrm{C}\end{array}$} & \multirow{2}{*}{$\begin{array}{c}\begin{array}{c}\text { Caffeine } \\
(\mu \mathrm{g} / \mathrm{mL})\end{array} \\
0.19 \pm 0.01^{\mathrm{gh}} \\
0.26 \pm 0.01^{\mathrm{de}} \\
0.26 \pm 0.02^{\mathrm{de}}\end{array}$} & \multirow{2}{*}{$\begin{array}{c}\begin{array}{c}\text { Phenolic } \\
(\mu \mathrm{g} / \mathrm{mL})\end{array} \\
106.78 \pm 0.18^{\mathrm{e}} \\
107.99 \pm 1.77^{\mathrm{de}} \\
140.19 \pm 1.48^{\mathrm{a}}\end{array}$} & \multirow{2}{*}{$\begin{array}{c}\begin{array}{c}\text { Carotenoid } \\
(\mu \mathrm{g} / \mathrm{mL})\end{array} \\
20.23 \pm 0.57^{\mathrm{g}} \\
26.39 \pm 0.23^{\mathrm{f}} \\
38.15 \pm 0.11^{\mathrm{e}}\end{array}$} & \multirow{2}{*}{$\begin{array}{c}\begin{array}{c}\text { Antioxidant } \\
(\mu \mathrm{M} / \mathrm{mL})\end{array} \\
587.20 \pm 6.79^{\mathrm{a}} \\
490.02 \pm 30.06^{\mathrm{b}} \\
567.91 \pm 15.92^{\mathrm{a}}\end{array}$} \\
\hline & $80^{\circ} \mathrm{C}$ & $\begin{array}{l}1 \text { min } \\
3 \text { min } \\
5 \text { min }\end{array}$ & & & & & \\
\hline & $90^{\circ} \mathrm{C}$ & $\begin{array}{l}1 \text { min } \\
3 \text { min } \\
5 \text { min }\end{array}$ & $\begin{array}{l}90^{\circ} \mathrm{C} \\
90^{\circ} \mathrm{C} \\
90^{\circ} \mathrm{C}\end{array}$ & $\begin{array}{l}0.25 \pm 0.01^{\mathrm{ef}} \\
0.31 \pm 0.01^{\mathrm{c}} \\
0.32 \pm 0.01^{\mathrm{bc}}\end{array}$ & $\begin{array}{l}116.20 \pm 4.33^{c} \\
111.00 \pm 2.93^{d} \\
120.41 \pm 0.89^{c}\end{array}$ & $\begin{array}{l}41.90 \pm 1.13^{\mathrm{bc}} \\
40.22 \pm 0.34^{\mathrm{d}} \\
41.10 \pm 0.28^{\mathrm{bcd}}\end{array}$ & $\begin{array}{l}428.82 \pm 3.83^{\mathrm{cd}} \\
405.82 \pm 10.49^{\mathrm{d}} \\
462.24 \pm 19.01^{\mathrm{bc}}\end{array}$ \\
\hline & $100^{\circ} \mathrm{C}$ & $\begin{array}{l}1 \mathrm{~min} \\
3 \mathrm{~min} \\
5 \mathrm{~min}\end{array}$ & $\begin{array}{l}100^{\circ} \mathrm{C} \\
100^{\circ} \mathrm{C} \\
100^{\circ} \mathrm{C}\end{array}$ & $\begin{array}{l}0.32 \pm 0.01^{\mathrm{bc}} \\
0.35 \pm 0.03^{\mathrm{b}} \\
0.39 \pm 0.06^{\mathrm{a}}\end{array}$ & $\begin{array}{c}108.03 \pm 2.67^{\mathrm{de}} \\
119.68 \pm 0.70^{\mathrm{c}} \\
95.83 \pm 2.94^{\mathrm{g}}\end{array}$ & $\begin{array}{l}42.26 \pm 0.45^{\mathrm{b}} \\
40.55 \pm 1.83^{\mathrm{cd}} \\
45.58 \pm 1.92^{\mathrm{a}}\end{array}$ & $\begin{array}{l}378.96 \pm 26.66^{\mathrm{d}} \\
407.68 \pm 15.56^{\mathrm{d}} \\
272.69 \pm 5.60^{\mathrm{e}}\end{array}$ \\
\hline \multirow[t]{3}{*}{ MAE } & $450 \mathrm{~W}$ & $\begin{array}{l}1 \mathrm{~min} \\
3 \mathrm{~min} \\
5 \mathrm{~min}\end{array}$ & $\begin{array}{l}36^{\circ} \mathrm{C} \\
51^{\circ} \mathrm{C} \\
59^{\circ} \mathrm{C}\end{array}$ & $\begin{array}{l}0.15 \pm 0.01^{\mathrm{i}} \\
0.17 \pm 0.01^{\mathrm{hi}} \\
0.21 \pm 0.01^{\mathrm{fg}}\end{array}$ & $\begin{array}{r}95.40 \pm 3.44^{\mathrm{g}} \\
88.35 \pm 2.86^{\mathrm{h}} \\
118.01 \pm 2.82^{\mathrm{c}}\end{array}$ & $\begin{array}{l}1.70 \pm 0.98^{1} \\
2.56 \pm 0.02^{\mathrm{kl}} \\
3.15 \pm 0.02^{\mathrm{kl}}\end{array}$ & $\begin{array}{l}385.77 \pm 36.50^{\mathrm{d}} \\
379.58 \pm 33.18^{\mathrm{d}} \\
411.41 \pm 21.14^{\mathrm{cd}}\end{array}$ \\
\hline & $630 \mathrm{~W}$ & $\begin{array}{l}1 \mathrm{~min} \\
3 \mathrm{~min} \\
5 \mathrm{~min}\end{array}$ & $\begin{array}{l}42^{\circ} \mathrm{C} \\
60^{\circ} \mathrm{C} \\
76^{\circ} \mathrm{C}\end{array}$ & $\begin{array}{l}0.15 \pm 0.01^{\mathrm{i}} \\
0.20 \pm 0.02^{\mathrm{gh}} \\
0.27 \pm 0.02^{\mathrm{de}}\end{array}$ & $\begin{array}{l}100.09 \pm 1.87^{\mathrm{f}} \\
106.36 \pm 2.13^{\mathrm{e}} \\
133.96 \pm 3.06^{\mathrm{b}}\end{array}$ & $\begin{array}{l}3.07 \pm 0.02^{\mathrm{jkl}} \\
4.35 \pm 0.09^{\mathrm{j}} \\
6.60 \pm 0.18^{\mathrm{i}}\end{array}$ & $\begin{array}{l}406.15 \pm 54.16^{\mathrm{d}} \\
390.13 \pm 30.17^{\mathrm{d}} \\
425.52 \pm 38.50^{\mathrm{cd}}\end{array}$ \\
\hline & $900 \mathrm{~W}$ & $\begin{array}{l}1 \text { min } \\
3 \text { min } \\
5 \text { min }\end{array}$ & $\begin{array}{l}43^{\circ} \mathrm{C} \\
71^{\circ} \mathrm{C} \\
89^{\circ} \mathrm{C}\end{array}$ & $\begin{array}{l}0.19 \pm 0.00^{\text {gh }} \\
0.24 \pm 0.02^{\text {ef }} \\
0.29 \pm 0.01^{\text {cd }}\end{array}$ & $\begin{array}{r}94.94 \pm 0.03^{g} \\
130.60 \pm 0.98^{\mathrm{b}} \\
132.96 \pm 0.41^{\mathrm{b}}\end{array}$ & $\begin{array}{c}3.34 \pm 0.05^{\mathrm{jk}} \\
6.29 \pm 0.91^{\mathrm{i}} \\
10.75 \pm 1.29^{\mathrm{h}}\end{array}$ & $\begin{array}{l}385.60 \pm 34.97^{\mathrm{d}} \\
418.13 \pm 20.87^{\mathrm{cd}} \\
413.44 \pm 27.70^{\mathrm{cd}}\end{array}$ \\
\hline
\end{tabular}

The same letters in the same column indicate that values are not significantly different $(p>0.05)$.

tivity in the aqueous extracts from both Arabica and Robusta coffee cherry peel were found in the conventional extraction process (Tables 2 and 3 ). Caffeine is a chemical compound that is naturally found in plants including coffee. It is soluble both in water and organic solvents [23]. Many antioxidative phenolics and carotenoids in plants are presented in covalently bound forms [24]. In this study, conventional extraction was more effective than the microwave-assisted extraction meth- ods. This is probably due to higher final temperature and longer extraction time used in conventional extraction since water is heated from room temperature to a much higher final temperature. The solutes are separated from the active sites in the sample matrix at greatly increased temperatures [16]. The extraction techniques using high temperature/power and longer holding times had a tendency to recover caffeine and total carotenoids more efficiently . Similar results were reported for 
caffeine from green tea leaves [22,25]. Thermal treatment of carotenoids in the presence of oxygen resulted in the formation of volatile compounds and non-volatile components [26]. However, two lutein dehydration products, 3,4 -didehydro- $\beta$, $\varepsilon$-caroten$3^{\prime}$-ol and $3^{\prime}, 4^{\prime}$ didehydro- $\beta, \beta$-caroten- 3 -ol, can be formed when vegetables are microwave-cooked at $700 \mathrm{~W}$ for $8 \mathrm{~min}$ [27]. Additionally, it is well established that carotenoids are highly hydrophobic compounds with extremely low water solubility. However, they were found in the aqueous extracts from both Arabica and Robusta coffee cherry peels. This was probably due to supramolecular complexes with natural water soluble oligosaccharides and polysaccharides that enhanced their solubility and stability [28]. Conventional extraction evidently produced higher quantities of total carotenoids than microwave-assisted extraction. This probably occurred since most carotenoids possess a high degree of hydrophobicity, and the supramolecular complexes of carotenoids require longer extraction times to separate them from the active sites of sample matrix [29]. Significant decreases in the quantities of total phenolics and antioxidant activity in the aqueous extracts were noted at temperatures higher than $90^{\circ} \mathrm{C}$. This is probably due to the thermally labile nature of antioxidative phenolics and carotenoids in plants [10]. There are many factors influencing the chemical stability of phenolics in aqueous extracts. These results can be related to previously published data. Muchuweti et al [30] and Chitindingu et al [31] reported that some vegetables are rich sources of phenolic compounds and that might contribute to their antioxidant activities. These components were affected differently when exposed to various processing techniques. This study demonstrated that conventional extraction could recover much higher quantities of bioactive compounds from dried coffee cherry peel byproducts than microwave-assisted extraction. This is probably due to the long extraction time of maceration by exposing materials to the solvent for greater periods of time. However, microwave-assisted extraction was a far more efficient extraction method for preserving antioxidant activity in aqueous extracts than the conventional extraction. The main reason for this was dipole rotation of the polar solvent (water) in the microwave field. Then, heat is produced throughout the extraction system and flows from the solvent to the sample $[32,33]$. Additionally, microwaves present an instantly controllable energy source that is precisely adjustable, and can be operated at lower temperatures with more rapid heating and reduced thermal gradients [10].

\section{CONCLUSION}

Extracts from coffee cherry peels were prepared in aqueous extracts from dried coffee cherry peel by-products using conventional and microwaveassisted extraction varying the temperature or power, respectively, along with holding time. Conventional extraction produced aqueous extracts with the higher quantities of caffeine and carotenoids. The optimal conventional water extraction and microwave-assisted extraction parameters providing extracts with the highest caffeine and carotenoids were $100^{\circ} \mathrm{C}$ with a 5 min holding time and $900 \mathrm{~W}$ of microwave power with 5 min holding time, respectively. The optimal microwave-assisted extraction parameters produced lower quantities of caffeine and carotenoids than the optimal conventional extraction. However, microwave-assisted produced extracts had higher antioxidant activities and the process required shorter extraction times than conventional processes. The optimal extraction parameters for dried Robusta coffee cherry peels were the same as those for Arabica.

Acknowledgements: This work was financially supported by Siam University.

\section{REFERENCES}

1. Somporn C, Kamtuo A, Theerakulpisut P, Siriamornpun S (2012) Effect of shading on yield, sugar content, phenolic acids and antioxidant property of coffee beans (Coffea arabica L. cv. Catimor) harvested from north-eastern Thailand. J Sci Food Agric 92, 1956-1963.

2. Agricultural Product Promotion Division (2018) Coffee, Department of Internal Trade of Thailand. Available at: agri.dit.go.th.

3. Esquivel P, Jiménez VM (2012) Functional properties of coffee and coffee by-products. Food Res Int 46, 488-495.

4. Knopp S, Bytof G, Selmar D (2006) Influence of processing on the content of sugars in green Arabica coffee beans. Eur Food Res Technol 223, ID 195.

5. Heeger A, Kosińska-Cagnazzo A, Cantergiani E, Andlauer W (2017) Bioactivities of coffee cherry pulp and its utilisation for production of Cascara beverage. Food Chem 221, 969-975.

6. Mussatto SI, Ballesteros LF, Martins S, Teixeira JA (2011) Extraction of antioxidant phenolic compounds from spent coffee grounds. Sep Purif Technol 83, 173-179.

7. Murthy PS, Naidu MM (2012) Recovery of phenolic antioxidants and functional compounds from 
coffee industry by-products. Food Bioprocess Tech 5, 897-903.

8. Viñas M, Gruschwitz M, Schweiggert RM, Guevara E, Carle R, Esquivel P, Jiménez VM (2012) Identification of phenolic and carotenoid compounds in coffee (Coffea arabica) pulp, peels and mucilage by HPLC electrospray ionization mass spectrometry. In: Proc 24th International Conference on Coffee Science, pp 127-135.

9. Simkin AJ, Kuntz M, Moreau H, McCarthy J (2010) Carotenoid profiling and the expression of carotenoid biosynthetic genes in developing coffee grain. Plant Physiol Biochem 48, 434-442.

10. Azmir J, Zaidul IS, Rahman MM, Sharif KM, Mohamed A, Sahena F, Jahurul MH, Ghafoor K, et al (2013) Techniques for extraction of bioactive compounds from plant materials: A review. J Food Eng 117, 426-436.

11. Hassas-Roudsari M, Chang PR, Pegg RB, Tyler RT (2009) Antioxidant capacity of bioactives extracted from canola meal by subcritical water, ethanolic and hot water extraction. Food Chem 114, 717-726.

12. Paré JJ, Bélanger JM, Stafford SS (1994) Microwaveassisted process (MAP): a new tool for the analytical laboratory. TrAC Trends Anal Chem 13, 176-184.

13. Alupului A, Calinescu I, Lavric V (2012) Microwave extraction of active principles from medicinal plants. UPB Sci Bull, B 74, 129-142.

14. AOAC International (1990) Methods of Analysis, 15th edn, Virginia.

15. Chindapan N, Soydok S, Devahastin S (2019) Roasting kinetics and chemical composition changes of robusta coffee beans during hot air and superheated steam roasting. $J$ Food Sci 84, 292-302.

16. Kenny O, O'Beirne D (2010) Antioxidant phytochemicals in fresh-cut carrot disks as affected by peeling method. Postharvest Biol Tec 58, 247-253.

17. Gross J (1991) Chlorophylls. In: Pigments in Vegetables, Springer, Boston, MA, pp 3-74.

18. Masuda T, Yonemori S, Oyama Y, Takeda Y, Tanaka T, Andoh T, Shinohara A, Nakata M (1999) Evaluation of the antioxidant activity of environmental plants: activity of the leaf extracts from seashore plants. $J$ Agric Food Chem 47, 1749-1754.

19. Thaipong K, Boonprakob U, Crosby K, CisnerosZevallos L, Byrne DH (2006) Comparison of ABTS, DPPH, FRAP, and ORAC assays for estimating antioxidant activity from guava fruit extracts. J Food Compos Anal 19, 669-775.

20. Murthy PS, Naidu MM (2012) Sustainable management of coffee industry by-products and value addition - A review. Resour Conserv Recyc 66, 45-58.

21. Somashekar KL, Anu Appaiah KA (2013) Coffee cherry husk - A potential feed stock for alcohol production. Int J Environ Waste Manag 11, 410-419.

22. Arellano-González MA, Ramírez-Coronel MA, TorresMancera MT, Pérez-Morales GG, Saucedo-Castañeda G (2011) Antioxidant activity of fermented and nonfermented coffee (Coffea arabica) pulp extracts. Food Technol Biotech 49, 374-378.

23. Agyemang-Yeboah F, Oppong SY (2013) Caffeine: the wonder compound, chemistry and properties. In: Agyemang-Yeboah Y, Asare-Anane H, Oppong SY (eds) Topical Series Health Sci 1, Research Signpost, India, pp 27-37.

24. Xu G, Ye X, Chen J, Liu D (2007) Effect of heat treatment on the phenolic compounds and antioxidant capacity of citrus peel extract. J Agric Food Chem 55, 330-335.

25. Pan X, Niu G, Liu H (2003) Microwave-assisted extraction of tea polyphenols and tea caffeine from green tea leaves. Chem Eng Process 42, 129-133.

26. Boon CS, McClements DJ, Weiss J, Decker EA (2010) Factors influencing the chemical stability of carotenoids in foods. Crit Rev Food Sci Nutr 50, 515-532.

27. Chen BH, Chen YY (1993) Stability of chlorophylls and carotenoids in sweet potato leaves during microwave cooking. J Agric Food Chem 41, 1315-1320.

28. Apanasenko IE, Selyutina OY, Polyakov NE, Suntsova LP, Meteleva ES, Dushkin AV, Vachali P, Bernstein PS (2015) Solubilization and stabilization of macular carotenoids by water soluble oligosaccharides and polysaccharides. Arch Biochem Biophys 572, 58-65.

29. Poojary MM, Barba FJ, Aliakbarian B, Donsí F, Pataro G, Dias DA, Juliano P (2016) Innovative alternative technologies to extract carotenoids from microalgae and seaweeds. Mar Drugs 14, ID 214.

30. Muchuweti M, Kativu E, Mupure CH, Chidewe C, Ndhlala AR, Benhura MA (2007) Phenolic composition and antioxidant properties of some spices. Am $J$ Food Technol 2, 414-420.

31. Chitindingu K, Ndhlala AR, Chapano C, Benhura MA, Muchuweti M (2007) Phenolic compound content, profiles and antioxidant activities of Amaranthus hybridus (pigweed), Brachiaria brizantha (upright brachiaria) and Panicum maximum (guinea grass). $J$ Food Biochem 31, 206-216.

32. Li Y, Fabiano-Tixier AS, Abert-Vian M, Chemat F (2012) Microwave-assisted extraction of antioxidants and food colors. In: Chemat F, Cravotto G (eds) Microwave-assisted Extraction for Bioactive Compounds, Food Engineering Series, Springer, Boston, MA, pp 103-125.

33. Poole CF (2019) Milestones in the development of liquid-phase extraction techniques. In: Poole CF (ed) Liquid-Phase Extraction, Elsevier, Netherlands, pp $1-44$. 